\title{
A skink out of water: impacts of anthropogenic disturbance on an Endangered reptile in Australian highland swamps
}

\author{
Sarsha Gorissen, Matthew Greenlees and Richard Shine
}

\begin{abstract}
The Blue Mountains water skink Eulamprus leuraensis is an Endangered swamp specialist known from $<60$ sites and restricted to the rare, threatened and fragmented habitat of Temperate Highland Peat Swamps on Sandstone. Understanding the species' ecology, notably its vulnerability to threatening processes such as hydrological disturbance, is essential if we are to retain viable populations of this Endangered reptile. We examined the impact of anthropogenic disturbance (longwall mining practices, development (industrial, urban, infrastructural) and damage by recreational vehicles) on this species, other herpetofauna and the swamp by surveying six paired undisturbed and disturbed sites in south-eastern Australia. The abundance of $E$. leuraensis was severely affected by disturbance. The species was absent from disturbed swamps, where it was replaced by its congener E. heatwolei and other woodland reptile species. Disturbance was associated with a halving of soil moisture content and a loss of surface water; the dense, live understorey was replaced by a sparser, drier habitat with dead vegetation, logs, rocks and bare ground. In effect, disturbance eliminated the distinctive features of the swamp habitat, transforming it into an area that resembled the surrounding habitat in terms of fauna, flora and physical characteristics. Our surveys suggest that hydrological disturbance (groundwater loss or alterations in surface water chemistry) extirpates E. leuraensis. This species' dependence on groundwater renders it sensitive to habitat degradation through hydrological disturbance. The conservation message for management authorities is clear: to protect the skink, protect the habitat.
\end{abstract}

Keywords Conservation, groundwater, hydrology, mining, mire, threatened ecosystem, threatened species, water pollution

\section{Introduction}

$1 \mathrm{n}$ essential first step in understanding the level of threat to a species is to determine its response to disturbance (Shine et al., 1998; Pike et al., 2010; Böhm et al., 2013).

Sarsha Gorissen (Corresponding author), Matthew Greenlees and Richard SHINE School of Life and Environmental Sciences, University of Sydney, Sydney, NSW 2006, Australia. E-mail sgorissen@uni.sydney.edu.au

Received 1 March 2016. Revision requested 1 April 2016.

Accepted 18 April 2016. First published online 26 September 2016.
Habitat loss and degradation are key causes of extinction of threatened wildlife worldwide (Gibbons et al., 2000; Hibbitts et al., 2013). Research into the impacts of disturbance on herpetofauna has focused on the global amphibian decline (e.g. Collins \& Storfer, 2003). A similar global decline may also be underway in reptiles but has attracted less research (Gibbons et al., 2000; Böhm et al., 2013), although localized declines and extinctions have been well documented (Cogger et al., 1993; Hecnar \& M'Closkey, 1998; Shine et al., 1998; Reading et al., 2010; Sinervo et al., 2010). Specialist, fragile or low-mobility species may be at greatest risk when environments change (Steffen et al., 2009). One such imperilled species is the Endangered Blue Mountains water skink Eulamprus leuraensis (ARASG, 1996).

This iconic reptile is known only from $<60$ isolated sites within the montane regions of south-eastern Australia (Blue Mountains and Newnes Plateau; Gorissen, 2016). It is endemic to a unique peat-swamp habitat, Temperate Highland Peat Swamps on Sandstone, which is also rare (c. 4,00o ha in extent; Hensen \& Mahony, 2010) and federally listed as Endangered (TSSC, 2005). Genetic studies show low rates of lizard dispersal, and thus gene flow, between these swamps (Dubey \& Shine, 2010), and even less genetic connectivity between the two main regions where such swamps occur (i.e. Blue Mountains water skinks on the Newnes Plateau are genetically distinct from those in the Blue Mountains; Dubey \& Shine, 2010). Climate change is expected to cause hotter and drier weather conditions in the area, reducing water availability (CSIRO \& BOM, 2007; IPCC, 2013). Longwall mining is an immediate and landscape-scale threat, given its detrimental and often severe impacts on swamps in this region (Aurecon, 2009; Goldney et al., 2010; Enforceable Undertaking, 2011) via groundwater loss through subsidence (and chemical pollution from mine-water discharge), and is listed as a Key Threatening Process in protective legislation (NSW Scientific Committee, 2005). Development (industrial, urban) and damage by vehicles are other threatening processes affecting swamps of the region (Hensen \& Mahony, 2010; Fryirs et al., 2012; Belmer et al., 2015) and may potentially degrade habitat quality for this Endangered reptile. We surveyed swamps exhibiting habitat degradation (and thus altered hydrological regimes), to clarify the impact of hydrological disturbance on E. leuraensis and its swamp habitat. 


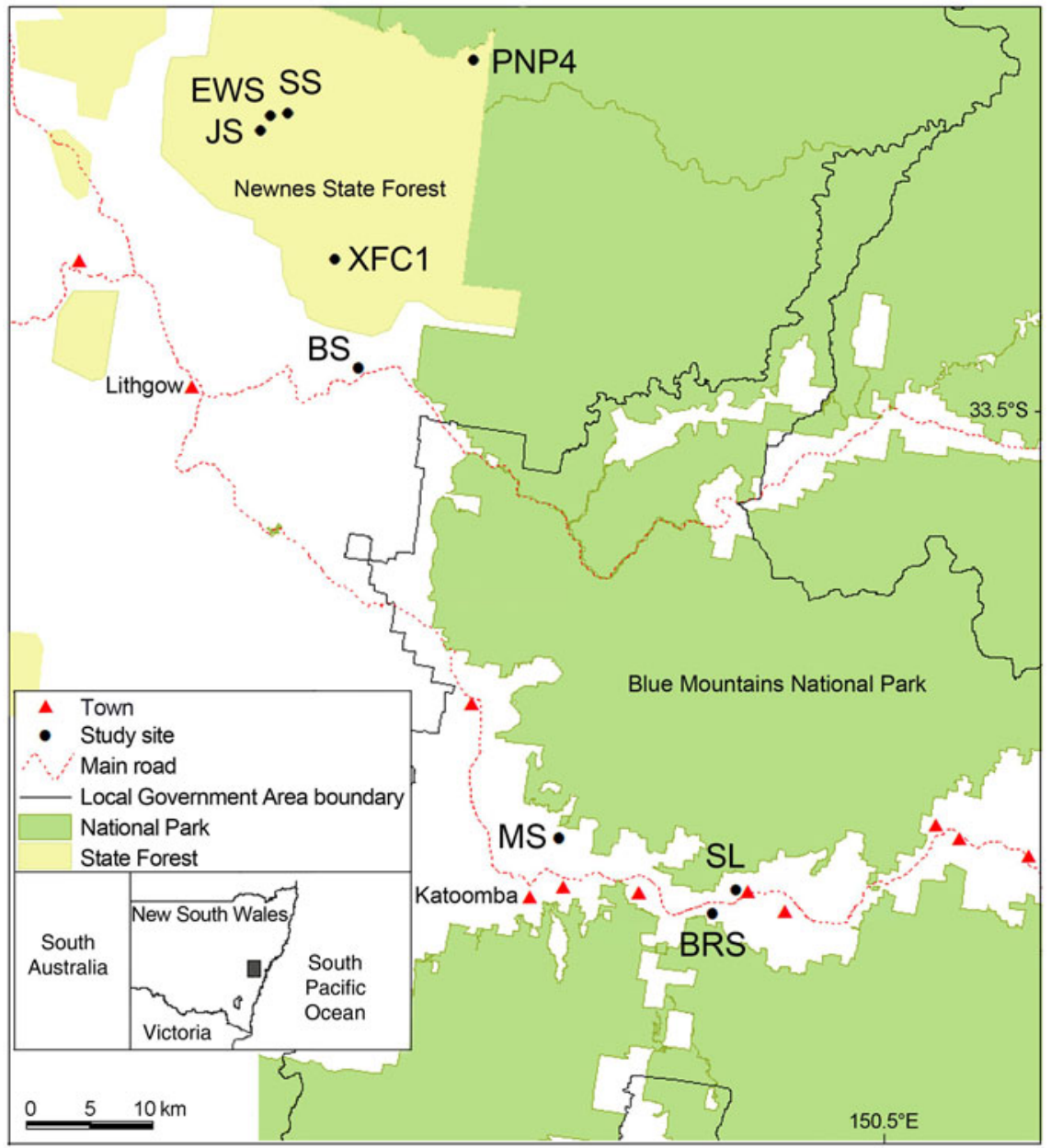

FIG. 1 Locations of the swamp sites surveyed in the Blue Mountains and Newnes Plateau areas of south-eastern Australia (NPWS, 2001; Table 1). BS, MS and XFC1 have both undisturbed and disturbed areas. (Adapted from Gorissen et al., 2015)

\section{Study area}

The Newnes Plateau and Blue Mountains areas of southeastern Australia, c. $100 \mathrm{~km}$ north-west of Sydney (Fig. 1), have a temperate climate, with mean monthly temperature of $6.3^{-23.1^{\circ} \mathrm{C}}$ (BOM, 2015), mean annual rainfall of $464^{-}$ 1,450 mm (Keith \& Benson, 1988; Whinam \& Chilcott, 2002; DEC, 2006), and an underlying sandstone geology (Keith \& Benson, 1988).

\section{Methods}

\section{Study sites}

The swamps sampled included Blue Mountains sedge swamps and Newnes Plateau shrub swamps (Keith \& Benson, 1988; Benson \& Baird, 2012). Islands within a matrix of sclerophyll woodland and open forest, these swamps are dominated by sedge, shrub and grass vegetation growing on peaty soils (Keith \& Benson, 1988; TSSC, 2005; Benson \& Baird, 2012). The swamps contain one or more drainage lines, and many are elongate in shape (Benson \& Baird, 2012). Nine such swamps were selected for surveys (Fig. 1,
Table 1), c. 3,500-120,000 $\mathrm{m}^{2}$ in extent, with mean elevations of $680-1,170 \mathrm{~m}$. Three swamps were pristine at one end but disturbed at the other (BS, MS, XFC1; Plate 1a), providing both control and treatment sites. We therefore sampled 12 sites in total (selected based on their level of disturbance), comprising six pairs of undisturbed and disturbed sites, paired by proximity and availability. All disturbed sites exhibited hydrological degradation, in terms of ground- and/ or surface-water quantity (loss through subsidence from longwall mining practices at EWS, (Plate $1 \mathrm{~b}$ ) and JS (Plate $1 \mathrm{c}, \mathrm{d})$ ), damage by recreational vehicles (XFC1 (Disturbed); Hensen, 2010) or development of infrastructure (MS (Disturbed); Fryirs et al., 2012). Surface-water quality was also affected (physical and/or chemical properties) by pollution and/or sedimentation as a result of industrial (BS (Disturbed); N. Belmer et al., unpubl. data) or urban development (BRS; Belmer et al., 2015). Eight of the study sites were on the Newnes Plateau, mainly within State Forests, at c. $1,100 \mathrm{~m}$ elevation, and four were in the Blue Mountains, on land managed by the Blue Mountains City Council, at c. $850 \mathrm{~m}$ elevation.

These 12 swamp sites span the entire known distributional range of the Blue Mountains water skink, which is the sole 
TABLE 1 Features of the six paired swamp sites in the Blue Mountains and Newnes Plateau areas of south-eastern Australia (Fig. 1), with swamp type, disturbance, hydrological impact, year of disturbance, elevation and area (Aurecon, 2009; Goldney et al., 2010; Belmer et al., 2015; M. Hensen, pers. comm., 2015).

\begin{tabular}{|c|c|c|c|c|c|c|}
\hline Swamp site (Type) & Swamp name & Disturbance & Hydrological impact & Year disturbed & Elevation $(\mathrm{m})$ & Area $\left(\mathrm{m}^{2}\right)$ \\
\hline \multicolumn{7}{|l|}{$\begin{array}{l}\text { Pair } 1 \\
\end{array}$} \\
\hline PNP4 (Undisturbed) & Upper Dinner Gully & & & & 973 & 42,400 \\
\hline JS (Disturbed) & Junction & $\begin{array}{l}\text { Longwall mining; } \\
\text { subsidence }\end{array}$ & Water loss & $2003-2004$ & 1,170 & 4,111 \\
\hline \multicolumn{7}{|l|}{ Pair 2} \\
\hline SS (Undisturbed) & Sunnyside & & & & 1,135 & 83,000 \\
\hline EWS (Disturbed) & East Wolgan & $\begin{array}{l}\text { Longwall mining; } \\
\text { subsidence; mine- } \\
\text { water discharge }\end{array}$ & Water loss & $2002-2009$ & 1,120 & 40,400 \\
\hline \multicolumn{7}{|l|}{ Pair 3} \\
\hline XFC1 (Undisturbed) & Happy Valley & & & & 1,075 & 119,018 \\
\hline XFC1 (Disturbed) & Happy Valley & $\begin{array}{l}\text { Vehicles } \\
\text { (recreational) }\end{array}$ & Water loss & Prior to 2006 & 1,085 & 2,922 \\
\hline \multicolumn{7}{|l|}{ Pair 4} \\
\hline BS (Undisturbed) & Browns & & & & 1,100 & 108,200 \\
\hline BS (Disturbed) & Browns & $\begin{array}{l}\text { Development } \\
\text { (industrial); } \\
\text { sedimentation }\end{array}$ & Water pollution & Prior to 2008 & 1,120 & 9,057 \\
\hline \multicolumn{7}{|l|}{ Pair 5} \\
\hline MS (Undisturbed) & Marmion Road & & & & 945 & 22,413 \\
\hline MS (Disturbed) & Marmion Road & $\begin{array}{l}\text { Development } \\
\text { (infrastructure) }\end{array}$ & Water loss & 2003-2004 & 960 & 1,925 \\
\hline \multicolumn{7}{|l|}{ Pair 6} \\
\hline SL (Undisturbed) & South Lawson & & & & 685 & 21,749 \\
\hline BRS (Disturbed) & Boronia Road & $\begin{array}{l}\text { Development } \\
\text { (urban); concrete } \\
\text { contamination }\end{array}$ & Water pollution & 2011-2012 & 755 & 3,790 \\
\hline
\end{tabular}

endemic vertebrate of the region (Fig. 1). Prior to surveying, pilot trapping established presence of the lizard in all undisturbed swamps. Of the three disturbed sites, the species was recorded prior to disturbance at JS and BRS (Fig. 1; NSW OEH, 2015) but not at EWS (Fig. 1). Although we lack a definite record of the species at the latter site, the area has remnant vegetation and some residual peat, typical of natural swamps, and shares common tributaries with neighbouring swamps that contain the species (SS, Fig. 1) or that have records of it (JS, Fig. 1). We inferred the historical presence of E. leuraensis in the disturbed sections of the remaining three swamps (BS, MS, XFC1), each of which contain both a pristine and a disturbed area, based on presence of the lizards in the pristine area of each swamp.

\section{Focal species}

Known from $<60$ populations, E. leuraensis is restricted in distribution (Gorissen, 2016) and listed as Endangered under both state and federal legislation (NPWS, 2001). Surveys suggest that the species is a swamp specialist $(>95 \%$ of occurrence records from swamps, and none from an equivalent trapping effort in surrounding woodland $<20 \mathrm{~m}$ from the swamp boundary; Gorissen et al., 2015). These scincid lizards are medium-sized (total length to $21.6 \mathrm{~cm}, \mathrm{c} .14 .8 \mathrm{~g}$ ), viviparous, and active on warm sunny days and during the hotter months (September to April/May). To escape predation E. leuraensis takes shelter in dense sedgeland tussocks or in holes in the peat substrate (Shea \& Peterson, 1985).

\section{Quantifying faunal abundance}

We quantified herpetofaunal and invertebrate abundances at paired swamp sites (disturbed and undisturbed) by mark-recapture over 3-day sessions during November 2014-March 2015. We divided the swamp ecosystem into three survey zones: swamp, transition (swamp margin) and woodland (Gorissen et al., 2015; Gorissen, 2016). Trapping was conducted only on days with a maximum temperature of $20-35^{\circ} \mathrm{C}$ and no rainfall (BOM, 2015). At each zone in each swamp we set 10 traps $\mathrm{C}$. $10 \mathrm{~m}$ apart. Pitfall traps (10 L, $27 \times 28 \mathrm{~cm}$; without drift fences; 1 per zone) and unbaited funnel traps $(18 \times 18 \times 75 \mathrm{~cm}$; 9 per zone) were used. Traps were checked in the late afternoon. 


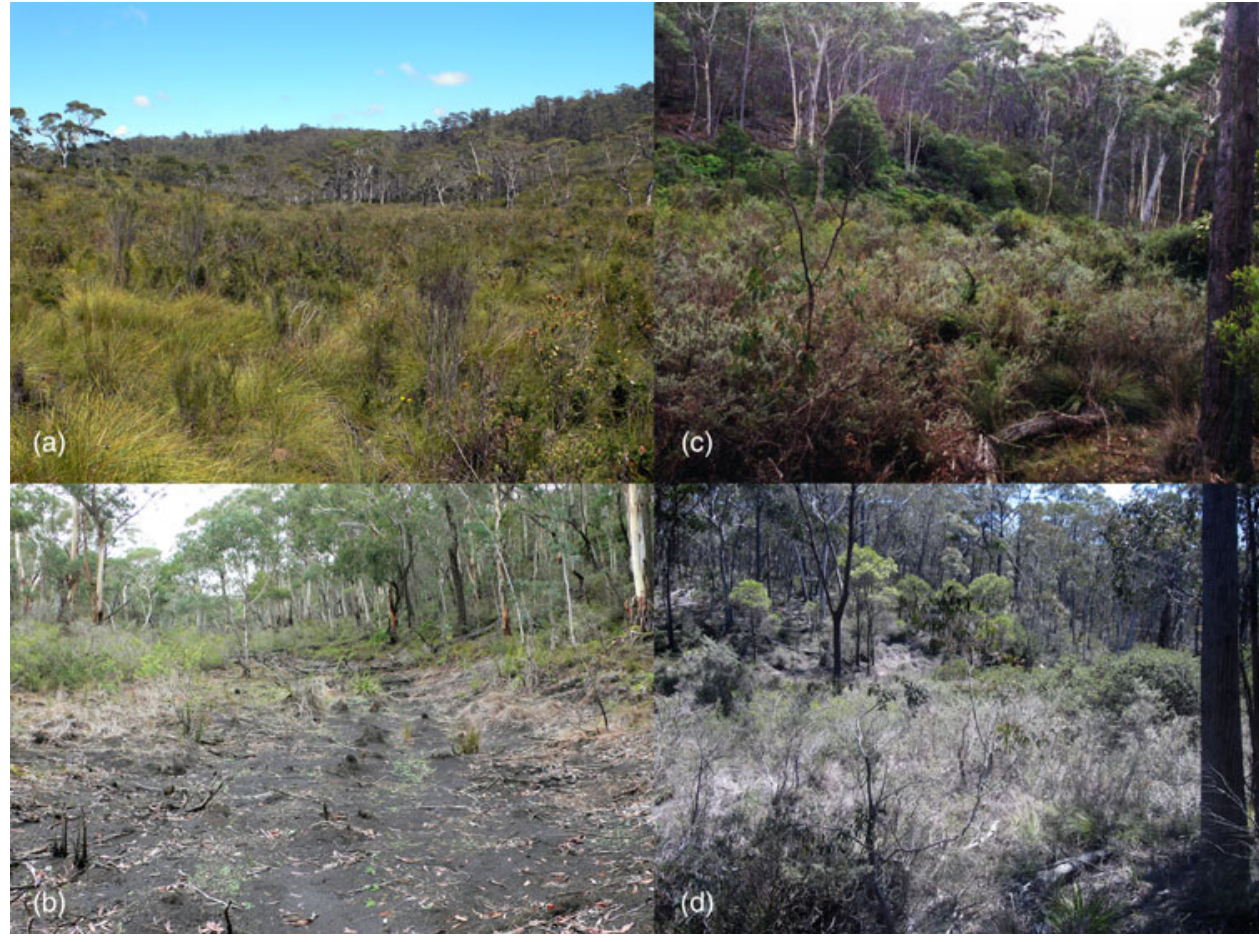

Plate. 1 Swamp sites on the Newnes Plateau. (a) Pristine, undisturbed bush swamp (XFC1) with a typical dense and live vegetation structure; (b) a disturbed swamp (EWS) with severe groundwater disturbance as a result of subsidence (and chemical pollution) from longwall mining practices; (c \& d) the site JS before (2001) and after (2014) the swamp was undermined (2003-2004).
Herpetofauna were identified to species, and invertebrates to order. Lizards were marked individually for later identification. Our index for population size was the number of individuals captured, excluding same-survey recaptures of individuals. Only live invertebrates were included, and we scored presence rather than abundance $(n=1)$ if the trap also contained material (usually scats) that served as an attractant to insects. In addition to records from ground traps we made some opportunistic sightings.

\section{Quantifying habitat characteristics}

SG recorded a suite of habitat characteristics around each trap for all three zones and all 12 swamp sites. Each quadrat was a circular area of $1 \mathrm{~m}$ radius, centred on the trap. Volumetric soil moisture content was calculated as the mean of three spatially randomized measurements from an MP406 Soil Moisture Instant Reading Kit (ICT International, Armidale, Australia). We also recorded the distance from surface water (drainage line or permanent pool $\geq 0.5 \mathrm{~m}$ diameter); the proportion of substrate covered by live vegetation, dead vegetation, log, surface water, rock, and bare ground (dirt or mud); the proportion of cover/sunlight penetration at the canopy $(>5 \mathrm{~m}$ high) and understorey (0.5-5 m high) levels; and the proportion of substrate exposed to direct sunlight at the sun's zenith. Distance measurements were made using a global positioning system, and canopy cover was approximated using a canopy cover estimation chart (Hnatiuk et al., 2009).

\section{Statistical analysis}

In all tests we compared disturbed vs undisturbed sites (i.e. a paired design) to control for locally variable factors. We evaluated normality and used paired statistical tests accordingly (a two-tailed $t$-test or Wilcoxon paired-sample test) to investigate the effects of swamp type (undisturbed vs disturbed; independent variable) on faunal abundances and habitat characteristics (dependent variables; see Table 2 for statistical tests). When differences in distributions were non-normal a standard $\log _{10}(x+1)$ transformation was applied (Zar, 1999). We used total abundance per swamp site as the unit for analyses (Table 2). Non-swamp lizards are taxa that (based on extensive surveys; Gorissen, 2016) usually inhabit the drier surrounding habitats (woodland and transitional zones) rather than the swamp itself (Gorissen, 2016). Our analyses of invertebrates included only species that are likely to be the prey of E. leuraensis (Veron, 1969; Brown, 1991; LeBreton, 1992, 1996).

\section{Results}

\section{Impacts on threatened and other fauna}

Eulamprus leuraensis occurred in all six undisturbed swamps but we did not record any in the six disturbed sites during our surveys (Fig. 2a, Table 2). Consistently, E. leuraensis was found in swamp habitat ( $>95 \%$ of records) and was the most abundant herpetofaunal species in this 
TABLE 2 Descriptive statistics for paired test results (two-tailed $t$-test; Wilcoxon paired-sample test) comparing undisturbed (U) vs disturbed (D) swamp types (for swamp habitat only, unless otherwise stated) in terms of faunal and habitat characteristics.

\begin{tabular}{lccccrrr}
\hline Variable & $\begin{array}{c}\text { Undisturbed } \\
(\text { mean } \pm \text { SE) }\end{array}$ & $\begin{array}{c}\text { Disturbed } \\
(\text { mean } \pm \text { SE) }\end{array}$ & Test & df/n & $t / S$ & P & Trend \\
\hline Abundance, E. leuraensis & $6.83 \pm 2.55$ & 0 & $t$-test & 5 & 6.82 & $0.0010^{*}$ & $\mathrm{U}>\mathrm{D}$ \\
Abundance, non-swamp lizards & $0.17 \pm 0.17$ & $2.50 \pm 0.72$ & $t$-test & 5 & -3.50 & $0.0173^{*}$ & $\mathrm{U}<\mathrm{D}$ \\
Abundance, total herpetofauna & $7.50 \pm 2.68$ & $2.83 \pm 0.79$ & $t$-test & 5 & 2.15 & 0.08 & \\
Abundance, invertebrates (prey) & $1.12 \pm 0.38$ & $1.32 \pm 0.21$ & $t$-test & 59 & -1.66 & 0.10 \\
Soil moisture content (\%) & $86.86 \pm 1.98$ & $45.13 \pm 4.49$ & Wilcoxon & 60 & 833.00 & $<0.0001^{*}$ & $\mathrm{U}>\mathrm{D}$ \\
Distance from water (m; all zones) & $38.59 \pm 2.58$ & $135.37 \pm 11.85$ & Wilcoxon & 180 & $-2,856.00$ & $<0.0001^{*}$ & $\mathrm{U}<\mathrm{D}$ \\
Substrate \%, live vegetation & $66.75 \pm 1.49$ & $46.00 \pm 3.63$ & Wilcoxon & 60 & 573.50 & $<0.0001^{*}$ & $\mathrm{U}>\mathrm{D}$ \\
Substrate \%, dead vegetation & $26.75 \pm 1.36$ & $32.83 \pm 2.80$ & $t$-test & 59 & -0.39 & 0.69 & \\
Substrate \%, log & $0.33 \pm 0.26$ & $1.50 \pm 0.54$ & Wilcoxon & 60 & -19.00 & 0.06 \\
Substrate \%, water & $4.33 \pm 0.81$ & $1.58 \pm 0.45$ & Wilcoxon & 60 & 116.00 & $0.0001^{*}$ & $\mathrm{U}>\mathrm{D}$ \\
Substrate \%, rock & 0 & $1.42 \pm 0.46$ & Wilcoxon & 60 & -27.50 & $0.0020^{*}$ & $\mathrm{U}<\mathrm{D}$ \\
Substrate \%, bare ground & $1.83 \pm 0.53$ & $15.92 \pm 3.37$ & Wilcoxon & 60 & -267.00 & $<0.0001^{*}$ & $\mathrm{U}<\mathrm{D}$ \\
Cover \%, canopy & $0.41 \pm 0.30$ & $2.41 \pm 1.14$ & Wilcoxon & 60 & -15.00 & 0.13 & \\
Cover \%, understorey & $66.08 \pm 2.05$ & $50.42 \pm 3.65$ & $t$-test & 59 & 4.37 & $<0.0001^{*}$ & $\mathrm{U}>\mathrm{D}$ \\
Cover \%, sunlight penetration & $35.42 \pm 1.90$ & $48.67 \pm 3.34$ & $t$-test & 59 & -4.01 & $0.0002^{*}$ & $\mathrm{U}<\mathrm{D}$ \\
\hline
\end{tabular}

${ }^{*}$ Statistically significant at $\mathrm{P}<0.05$

habitat within undisturbed swamps (E. leuraensis, $\mathrm{n}=41$; other herpetofauna, $n=4)$. We trapped more non-swamp lizards in the swamp habitat in disturbed sites than in undisturbed sites (Table 2), notably the skinks Acritoscincus platynota $(\mathrm{n}=4)$, Eulamprus heatwolei $(\mathrm{n}=3)$ and Lampropholis guichenoti $(\mathrm{n}=4)$. In undisturbed swamps, in contrast, $E$. heatwole $i$ was trapped only in the swamp margins. The numbers of original vs regrown tails were similar in lizards from both swamp types $\left(\chi_{1}^{2}=0.34, \mathrm{P}=0.56\right)$.

Overall, 12 species of herpetofauna were captured in undisturbed swamps, and nine in disturbed swamps, with an equal species richness in swamp habitat in both disturbed and undisturbed sites (five species). The total abundance of herpetofauna was similar for both swamp types (Table 2).

Within the swamp habitat, invertebrates were equally abundant in disturbed and undisturbed sites (Table 2). Arthropods were the most common invertebrates. Notable species in the swamp included the burrow-forming Sydney crayfish Euastacus australasiensis and the burrow-forming and Endangered giant dragonfly Petalura gigantea, both of which were found in undisturbed but not disturbed swamp habitat.

\section{Habitat degradation}

Predictably, soil moisture declined with distance from water ( $\left.\mathrm{n}=358, r^{2}=0.16, \mathrm{P}<0.0001\right)$. Disturbed swamps were further from water and had drier soil, with volumetric soil moisture content approximately half that of undisturbed swamps (Table 2). Substrate composition also changed with degradation, from a swamp habitat with abundant live vegetation and surface water (with almost no rocks, logs or bare ground) to one with more bare ground, rocks and dead vegetation (including logs; Fig. 2b, Table 2). Disturbance was also associated with a reduced understorey density and increased sunlight penetration to ground level within the swamp habitat (Fig. 2c, Table 2). Transition and woodland habitat characteristics were relatively unaffected by disturbance to the swamp (S. Gorissen et al., unpubl. data). Although the direction of these trends is predictable, the shift in habitat characteristics (especially water availability) following disturbance is striking.

\section{Discussion}

Our surveys reveal a stark impact of anthropogenic disturbance on the distribution and abundance of the Endangered Blue Mountains water skink. Although found in all of the undisturbed swamps that we surveyed, these lizards were not caught in any of the disturbed swamps. Earlier surveys and records suggest that E. leuraensis occurred previously in at least five of the six disturbed swamps, and probably in all six. The loss of this iconic taxon is consistent with the species' restriction to densely vegetated and wet swamp habitat (Gorissen et al., 2015; this study), its lower abundance in urban than in bush swamps (Gorissen et al., 2015), and the changes to its habitat that follow anthropogenic disturbance (this study). Most obviously, the disturbed swamps were drier than pristine swamps, resembling habitats that previously surrounded the swamp itself (Gorissen, 2016). In keeping with that change, disturbed swamps contained lizard species typical of these transitional and woodland habitats, rather than the swamp-specialist E. leuraensis (Gorissen, 2016).

Our sample size was limited by the small geographical range of the focal species, the limited availability of 

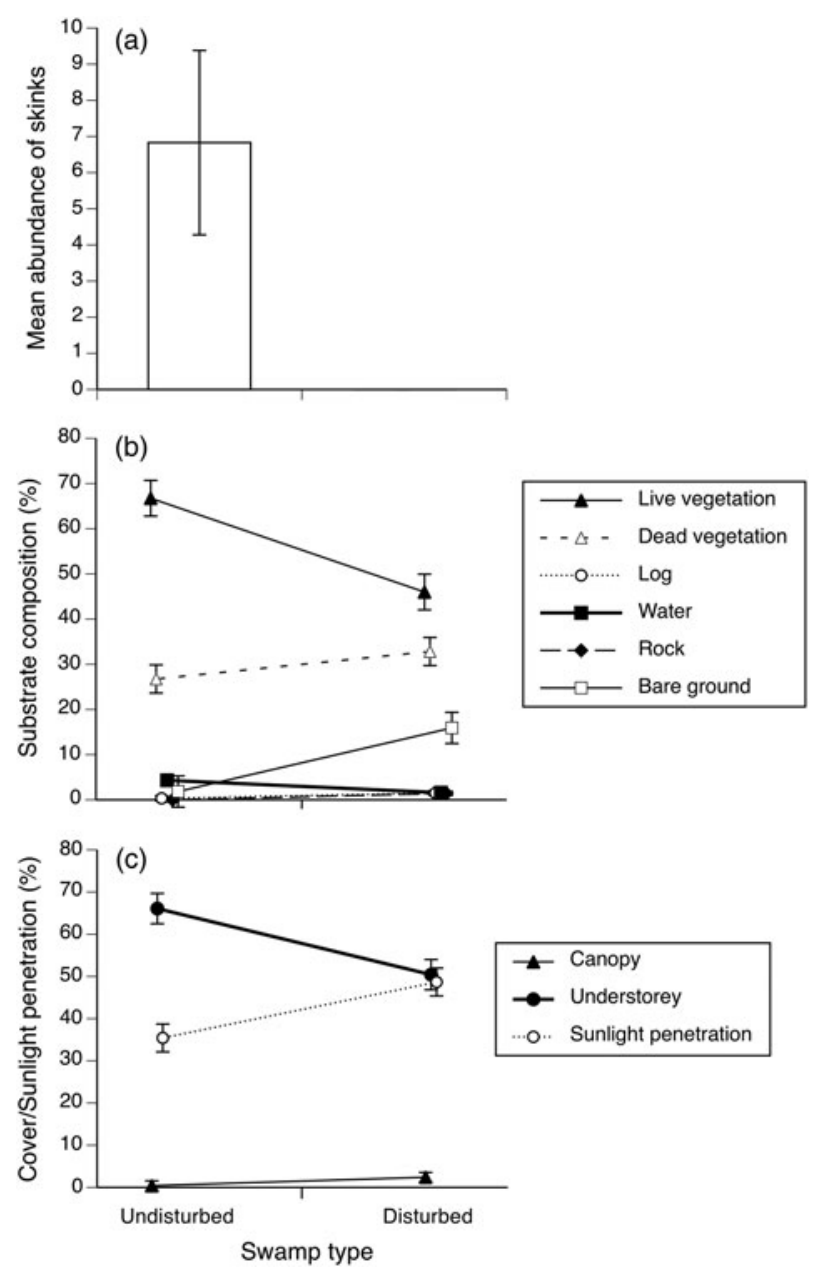

FIG. 2 Attributes of undisturbed vs disturbed swamp sites surveyed in the Blue Mountains and Newnes Plateau areas of south-eastern Australia (Fig. 1). (a) Mean abundance of the Blue Mountains water skink Eulamprus leuraensis; (b) substrate composition (\% of ground covered by live vegetation, dead vegetation, log, water, rock and bare ground) of swamp habitat; and (c) vegetation cover (canopy and understorey) and sunlight penetration to ground level of swamp habitat.

disturbed swamp habitat, and a paucity of pre-disturbance survey data for most swamps (precluding a BACI (BeforeAfter Control-Impact) experimental design; Quinn \& Keough, 2002). Consequently, three of our sampling sites included both undisturbed and disturbed sub-sites, which potentially were not truly independent. However, these subsites were distinct both spatially and in terms of habitat characteristics. If we had failed to find differences between undisturbed and disturbed areas so close together one could argue that migration of lizards, for example, had obscured a pattern that would otherwise have been evident. However, the fact that we detected clear differences in lizard abundance despite the close proximity of the undisturbed and disturbed swamp areas reinforces our conclusions. Four of the six disturbed swamps had lost much of their water, and therefore the simultaneous loss of a water skink is unsurprising. Nonetheless, the congeneric water skink $E$. heatwolei, whose distribution is less closely tied to waterlogged habitats (Gorissen, 2016), not only persisted around these swamps but moved into the swamps vacated by $E$. leuraensis. Manipulative experiments would be needed to explore whether that habitat expansion was facilitated simply by the habitat shift, or by release from interspecific agonistic interactions (Done \& Heatwole, 1977).

The absence of E. leuraensis from disturbed swamps may reflect a physiological dependence on moist conditions (e.g. because of high rates of evaporative water loss; Heatwole \& Veron, 1977; Greer, 1989; Neilson, 2002) or an ecological dependence on specific habitat attributes that persist only where soil moisture levels are high. Again, manipulations could decipher these possibilities. The loss of E. leuraensis from two swamps where water quantity was unaffected but water quality was compromised suggests that habitat features other than simply moisture levels may be important for this Endangered species. In keeping with this interpretation, many aspects of vegetation cover shifted significantly in our disturbed sites (especially when water was removed from the system). However, patches of relatively dense cover remained in some disturbed sites, and the frequency of caudal autotomy-often used as an index of predation risk (Smith \& Ballinger, 2001) and/or of the frequency of failed predation attempts (Schwarzkopf \& Shine, 1992) did not differ between lizards in disturbed vs undisturbed swamps. Similarly, the abundance of invertebrate prey was not modified substantially by habitat disturbance. The vulnerability of $E$. leuraensis populations in the disturbed swamps may have been exacerbated by the relatively small spatial extent of most of these sites (Table 1).

The relative similarity in total herpetofaunal abundance between disturbed and undisturbed sites suggests that some species (such as E. leuraensis) are negatively affected by anthropogenic disturbance, whereas others (such as E. heatwolei) benefit. The taxa that thrive tend to be generalist woodland species, none of which are categorized as threatened (possibly reflecting the broad availability of this habitat type). The victims of anthropogenic degradation of swamps are the habitat specialists, at least one of which (E. leuraensis) is of major conservation concern (NPWS, 2001). In essence, swamp degradation reduces the availability of a scarce habitat type, replacing it with an already widespread habitat type. The consequences for faunal conservation are unlikely to be positive.

Translocation is a potential but unexplored management response to disturbance, and may assist in the conservation of E. leuraensis. Some of the swamps in this region are at risk of hydrological disturbance as a result of longwall mining on the Newnes Plateau, a stronghold for this Endangered reptile. We could capture lizards from imminently threatened sites and translocate them to novel (currently lizard-free) swamps to maintain genetic diversity within the species 
(Dubey \& Shine, 2010). Biological aspects of the species that could be capitalized upon for this process include its low dispersal rate, high habitat specificity and high reproductive rate (compared to congeneric skinks in this montane environment). Analogously, Templeton et al. (2011) translocated populations of the eastern collared lizard Crotaphytus collaris collaris to combat local extinction without recolonization within a patchy habitat.

In summary, the Blue Mountains water skink is a habitat specialist that is restricted to $<60$ groundwater-dependent swamps within an area subject to major anthropogenic pressure (e.g. Wright, 2011; Benson \& Baird, 2012; Fryirs et al., 2012; Belmer et al., 2014, 2015). Habitat loss or degradation of any of these sites would further threaten this already Endangered species. Especially given its low vagility, E. leuraensis may be vulnerable to habitat change wrought by climate change, urban pollution and longwall mining activity (Dubey \& Shine, 2010). To conserve E. leuraensis in the wild, its rare, fragile and distinctive swamp habitat must be shielded from hydrological disturbance such as groundwater loss and surface water contamination. To conserve the genetic diversity of the species and hence maximize its resilience to any localized adverse impacts we must conserve populations from across its current range (and ideally from as many isolated swamps as is practical). To protect this species we must protect its habitat.

\section{Acknowledgements}

We thank our fieldworkers, in particular Stephanie and Peter Bamford, Greg Clarke, Willem Gorissen and Heinz Neubauer. We thank Deborah Ashworth, Ian Baird, Michael Hensen, Chris and Julie Jonkers, Martin Krogh and Keith Muir for discussions. Nakia Belmer provided water chemistry data, Ray Mjadwesch provided photographs, and Melanie Elphick assisted with editing. We also thank the Fenner School of Environment and Society (Australian National University), Blue Mountains City Council, Humane Society International, Ecological Society of Australia, Australian Wildlife Society, University of Sydney and the Australian Research Council for funding. All research was conducted under the University of Sydney Animal Care and Ethics Committee authorization \#L04/12-2012/3/5890; National Parks and Wildlife Service Scientific Licence \#SL101112; and Forestry Corporation Permits \#PB52916 and \#PB54029.

\section{Author contributions}

SG conceived the study and conducted the research. SG, MG and RS designed the study. SG and RS analysed the data and wrote the article.

\section{References}

ARASG (Australasian Reptile \& Amphibian Specialist Group) (1996) Eulamprus leuraensis. The IUCN Red List of Threatened Species 1996: e.T8187A12896001. Http://dx.doi.org/10. 2305/IUCN.UK.1996.RLTS.T8187A12896001.en [accessed 17 April 2016].

Aurecon (2009) Newnes Plateau Shrub Swamp Management Plan. Investigation of Irregular Surface Movement within East Wolgan Swamp. Report Reference: 7049-010-Rev 3. Centennial Coal, Sydney, Australia.

Belmer, N., Tippler, C., Davies, P.J. \& Wright, I.A. (2014) Impact of a coalmine waste discharge on water quality and aquatic ecosystems in the Blue Mountains World Heritage Area. In Proceedings of the 7 th Australian Stream Management Conference, July 2014, Townsville, Australia, pp. 385-391.

Belmer, N., Wright, I.A. \& Tippler, C. (2015) Urban geochemical contamination of high conservation value upland swamps, Blue Mountains Australia. Water, Air, \& Soil Pollution, 226, 1-5.

BENSON, D. \& BAIRD, I.R.C. (2012) Vegetation, fauna and groundwater interrelations in low nutrient temperate montane peat swamps in the upper Blue Mountains, New South Wales. Cunninghamia, 12, 267-307.

Böhm, M., Collen, B., Baillie, J.E.M., Bowles, P., Chanson, J., Cox, N. et al. (2013) The conservation status of the world's reptiles. Biological Conservation, 157, 372-385.

BOM (Bureau of Meteorology) (2015) Climate Data Online. Http://www.bom.gov.au/climate/data/ [accessed 1 October 2015]

Brown, G.W. (1991) Ecological feeding analysis of south-eastern Australian scincids (Reptilia, Lacertilia). Australian Journal of Zoology, 39, 9-29.

Cogger, H.G., Cameron, E., Sadlier, R. \& Eggler, P. (1993) The Action Plan for Australian Reptiles. Australian Nature Conservation Agency, Canberra, Australia.

Collins, J.P. \& S Torfer, A. (2003) Global amphibian declines: sorting the hypotheses. Diversity and Distributions, 9, 89-98.

CSIRO \& BOM (Commonwealth SCientific and Industrial Research Organisation and Bureau of Meteorology) (2007) Climate Change in Australia: Observed Changes and Projections. Technical report. Http://ccia2007. climatechangeinaustralia.gov.au/technical_report.php [accessed 1 October 2015].

DEC (Department of Environment and Conservation) (2006) The Vegetation of the Western Blue Mountains, Including the Capertee, Coxs, Jenolan and Gurnang Areas. Volume 2: Vegetation Community Profiles. Http://www.environment.nsw.gov.au/ resources/nature/vegOfWbluemtsVoliTech.pdf [accessed 1 October 2015].

Done, B.S. \& Heatwole, H. (1977) Social behavior of some Australian skinks. Copeia, 1977, 419-430.

Dubey, S. \& Shine, R. (2010) Restricted dispersal and genetic diversity in populations of an endangered montane lizard (Eulamprus leuraensis, Scincidae). Molecular Ecology, 19, 886-897.

ENFORCEABLE UNDERTAKING (2011) Enforceable Undertaking Under Section 486DA of the EPBC Act by the Federal Minister for Sustainability, Environment, Water, Population, and Communities by Springvale Coal Pty Ltd and Centennial Angus Place Pty Ltd. Https://www.environment.gov.au/system/files/news/ a7fcc8b7-8efc-4be5-a687-7b62e80398a8/files/ enforceable-undertaking-centennial.pdf [accessed 1 October 2015].

Fryirs, K., Freidman, B. \& Kohlhagen, T. (2012) The formation and geomorphic condition of upland swamps in the Blue Mountains: rehabilitation potential of these endangered ecosystems. In Proceedings of the 6th Australian Stream Management 
Conference: Managing for Extremes, February 2012, Canberra, Australia, pp. 574-580.

Gibbons, J.W., Scott, D.E., Ryan, T.J., Buhlmann, K.A., Tuberville, T.D., Mets, B.S. et al. (2000) The global decline of reptiles, déjà vu amphibians. BioScience, 50, 653-666.

Goldney, D., Mactaggart, B. \& Merrick, N. (2010) Determining Whether or Not a Significant Impact Has Occurred on Temperate Highland Peat Swamps on Sandstone Within The Angus Place Colliery Lease on The Newnes Plateau. Report prepared for the Department of the Environment, Water, Heritage and the Arts, January 2010.

Gorissen, S. (2016) Conservation biology of the endangered Blue Mountains water skink (Eulamprus leuraensis). $\mathrm{PhD}$ thesis. The University of Sydney, Sydney, Australia.

Gorissen, S., Mallinson, J., Greenlees, M. \& Shine, R. (2015) The impact of fire regimes on populations of an endangered lizard in montane south-eastern Australia. Austral Ecology, 40, 170-177.

Greer, A.E. (1989) The Biology and Evolution of Australian Lizards. Surrey Beatty and Sons, Chipping Norton, Australia.

Heatwole, H. \& Veron, J.E.N. (1977) Vital limit and evaporative water loss in lizards (Reptilia, Lacertilia): a critique and new data. Journal of Herpetology, 11, 341-348.

Hecnar, S.J. \& M'Closkey, R.T. (1998) Effects of human disturbance on five-lined skink, Eumeces fasciatus, abundance and distribution. Biological Conservation, 85, 213-222.

Hensen, M. (2010) Newnes Plateau Shrub Swamp Aerial Assessment Project Report 2010. Save Our Swamps Project, Blue Mountains City Council, Katoomba, Australia.

Hensen, M. \& Mahony, E. (2010) Reversing drivers of degradation in Blue Mountains and Newnes Plateau shrub swamp endangered ecological communities. Australasian Plant Conservation, 18, 5-6.

Hibittts, T.J., Ryberg, W.A., Adams, C.S., Fields, A.M., Lay, D. \& Young, M.E. (2013) Microhabitat selection by a habitat specialist and a generalist in both fragmented and unfragmented landscapes. Herpetological Conservation and Biology, 8, 104-113.

Hnatiuk, R.J., Thackway, R. \& Walker, J. (2009) Vegetation. In Australian Soil and Land Survey Field Handbook, 3 rd edition (ed. The National Committee on Soil and Terrain), pp. 73-125. CSIRO Publishing, Collingwood, Australia.

IPCC (Intergovernmental Panel on Climate Change) (2013) Climate Change 2013: The Physical Science Basis. Contribution of Working Group 1 to the Fifth Assessment Report of the Intergovernmental Panel on Climate Change (eds T.F. Stocker, D. Qin, G.-K. Plattner, M. Tignor, S.K. Allen, J. Boschung et al.). Cambridge University Press, Cambridge, UK, and New York, USA. Https://www.ipcc.ch/pdf/assessment-report/ar5/wg1/WG1AR5_ Frontmatter_FINAL.pdf [accessed 1 October 2015].

Keith, D.A. \& Benson, D.H. (1988) The natural vegetation of the Katoomba 1:100 ooo map sheet. Cunninghamia, 2, 107-144.

LeBreton, M. (1992) Notes on the Blue Mountains water skink, Costinisauria leuraensis (Wells and Wellington) (Lacertilia: Scincidae). Sydney Basin Naturalist, 1, 101-103.

LeBreton, M. (1996) Habitat and distribution of the Blue Mountains swamp skink (Eulamprus leuraensis). BSc thesis. University of New South Wales, Sydney, Australia.

NeILSON, K.A. (2002) Evaporative water loss as a restriction on habitat use in endangered New Zealand endemic skinks. Journal of Herpetology, 36, 342-348.

NPWS (National Parks and Wildife Service) (2001) Blue Mountains Water Skink (Eulamprus leuraensis) Recovery Plan. New South Wales NPWS, Hurstville, Australia.

NSW OEH (New South Wales Office of Environment and Heritage) (2015) Atlas of NSW Wildife. Http://www.bionet.nsw. gov.au/ [accessed 20 May 2015].
NSW Scientific Committee (2005) Alteration of Habitat Following Subsidence Due to Longwall Mining. NSW Scientific Committee Key Threatening Process Final Determination. Http://www.environment. nsw.gov.au/determinations/LongwallMiningKtp.htm [accessed 3 November 2015].

Pike, D.A., Croak, B.M., Webb, J.K. \& Shine, R. (2010) Subtle but easily reversible anthropogenic disturbance seriously degrades habitat quality for rock-dwelling reptiles. Animal Conservation, 13, 411-418.

Quinn, G.P. \& Keough, M.J. (2002) Experimental Design and Data Analysis for Biologists. Cambridge University Press, Cambridge, UK.

Reading, C.J., Luiselli, L.M., Akani, G.C., Bonnet, X., Amori, G., BALlouard, J.M. et al. (2010) Are snake populations in widespread decline? Biology Letters, 6, 777-780.

Schwarzkopf, L. \& Shine, R. (1992) Costs of reproduction in lizards: escape tactics and susceptibility to predation. Behavioral Ecology and Sociobiology, 31, 17-25.

Shea, G.M. \& Peterson, M. (1985) The Blue Mountains water skink, Sphenomorphus leuraensis (Lacertilia: Scincidae): a redescription, with notes on its natural history. Proceedings of the Linnean Society of New South Wales, 108, 141-148.

Shine, R., Webb, J.K., Fitzgerald, M. \& Sumner, J. (1998) The impact of bush-rock removal on an endangered snake species, Hoplocephalus bungaroides (Serpentes: Elapidae). Wildlife Research, $25,285-295$.

Sinervo, B., Méndez-de-la-Cruz, F., Miles, D.B., Heulin, B., Bastiaans, E., Villagrán Santa Cruz, M. et al. (2010) Erosion of lizard diversity by climate change and altered thermal niches. Science, 328, 894-899.

SMith, G.R. \& BALLINGER, R.E. (2001) The ecological consequences of habitat and microhabitat use in lizards: a review. Contemporary Herpetology, Number 3. Http://jnah.cnah.org/ch/ch/2001/3/ [accessed 1 October 2015].

Steffen, W., Burbidge, A.A., Hughes, L., Kitching, R., Lindenmayer, D., Musgrave, W. et al. (2009) Australia's Biodiversity and Climate Change: A Strategic Assessment of the Vulnerability of Australia's Biodiversity to Climate Change. Report to the Natural Resource Management Ministerial Council commissioned by the Australian Government. CSIRO Publishing, Canberra, Australia.

Templeton, A.R., Brazeal, H. \& Neuwald, J.L. (2011) The transition from isolated patches to a metapopulation in the eastern collared lizard in response to prescribed fires. Ecology, 92, 1736-1747.

TSSC (Threatened Species Scientific Committee) (2005) Temperate Highland Peat Swamps on Sandstone: Advice to the Minister for the Environment and Heritage from the Threatened Species Scientific Committee (TSSC) on amendments to the List of Ecological Communities under the Environment Protection and Biodiversity Conservation Act 1999 (EPBC Act). Department of Environment and Water Resources (Commonwealth). Http://www. environment.gov.au/node/14561 [accessed 1 October 2015].

Veron, J.E.N. (1969) An analysis of stomach contents of the water skink, Sphenomorphus quoyi. Journal of Herpetology, 3, 187-189.

Whinam, J. \& Снilcotт, N. (2002) Floristic description and environmental relationships of Sphagnum communities in NSW and the ACT and their conservation management. Cunninghamia, 7, 463-500.

Wright, I.A. (2011) Coal mine 'dewatering' of saline wastewater into NSW streams and rivers: a growing headache for water pollution regulators. In Proceedings of the 6th Australian Stream Management Conference: Managing for Extremes, February 2012, Canberra, Australia, pp. 206-213.

ZAR, J.H. (1999) Biostatistical Analysis. Volume 4. Prentice Hall, Upper Saddle River, USA. 


\section{Biographical sketches}

SARSHA GORISSEn primarily researches the conservation of wildlife, in particular, the conservation biology and ecology of threatened species to develop better management guidelines. MAтTHEW GREENLEES researches the ecology and evolution of Australian her- petofauna and has a broad interest in natural history, with a particular focus on the impacts of anthropogenic activities and invasive species. RICHARD SHINE's research concerns the interface between evolution and ecology, particularly in reptiles, with recent work focusing on major issues in conservation, especially the biology, impact and control of invasive species such as the cane toad. 